
\section{V-13 下大静脈後尿管に対する腹胵鏡下尿管形成}

宇治徳洲会病院 泌尿器科 1

滋賀医科大学 医学部 泌尿器科 ${ }^{2)}$

小泉 修一" 加藤 研次郎" 若林 賢彦2) 片岡 晃 ${ }^{21}$ 岡田 裕作 ${ }^{2)}$

【目的】下大静脈後录管に対する腹腔鏡下尿管形成術を経験した のでビデオにて供覽する。【症例】28歳、女性。両側の背部痛に て左尿管結石上下大静脈後尿管を発見された。【手術方法】全身 麻酔下に、まず砕石位で右尿管に尿管カテーテルを留置した。左 側臥位とし、偤窩に1本および鎖骨中線上に 2 本の $12 \mathrm{~mm}$ 外套管を 穿刺し、上行結腸を内側翻展後に下大静脈交叉部の上下で尿管を 確保した。さらに前腋简線上に $5 \mathrm{~mm}$ 外套管を追加し尿管を切断 後、下大静脈前面に整復し、シングルJカテーテルを留置の上、5-0 バイクリル系6針で尿管端々吻合を行った。【結果】手術時間は、 6時間55分で尿管吻合に時間を要した。手術翌日より歩行、摂食 可能で、術後5日目にダブルJカテーテルに交換し9日目に退院し た。【考察】下大静脈後尿管に対する腹腔鏡下手術は低侵襲手術 として有用と思われた。

\section{腹腔鏡 下大静脈後尿管 尿管吻合術}

\section{Impacted stone に対する後腹膜鏡下尿管切} 石術の有用性について

\author{
福岡大学 医学部 泌尿器科学教室 ${ }^{1)}$ 原三信病院 ${ }^{2)}$ \\ 白十字病院 ${ }^{3)}$ \\ 田丸 俊三”道永 成 ${ }^{2}$ 北城 守文 ${ }^{2)}$ 種子田 洋史 ${ }^{31}$ \\ 过 祐治 ${ }^{1}$
}

【目的】嵌頓期間の長い結石やガイドワイヤーが挿入困難な症例 には治療に難橴することが多い．今回impacted stone の症例に対 し後腹膜鏡下に尿管切石術を行い, 良好な結果を得たので報告す る.【対象上方法】対象は, 1998年2月から現在までに後腹膜鏡 下尿管切石術を施行した5例. 全身麻酔下に体位は半側臥位とし， open laparoscopy の手技にて第1ポートを作製し, balloon dissector を用い後腹膜腔の剥離を行った，同部位をカメラポートとし，操 作ポートは2-3本のトロカールを追加した，後腹膜鏡下に体腔鏡 用超音波探触子を挿入し超音波画面で結石の位置を確認し, 必要 最小限の尿管（結石の位置する）の剥離を行い尿管切石術を行っ た，尿管切開部の䋖合とD-Jカテーテルの留置は必要に応じて行 った，全例，後腹膜腔にドレーンを留置し手術を終了した。

【結果】全例で残石なく結石を摘出できた。平均手術時間は 232 分, 平均出血量は $36 \mathrm{~g}$, 平均ドレーン留置期間3日. 術中・術後の 合併症は認めなかった。【結論】尿管結石に対する後腹膜鏡下尿 管切石術は, 低侵襲であり, 合併症むなく術後の回復も良好であ った。 また，残石なく結石の摘除が可能で， impacted stoneなど の治療抵抗性の尿管結石に対し有用な治療法之考えられた.

後腹膜鏡下尿管切石術 Impacted stone 体腔鏡用超音波 探触子

\section{V-15 鏡視下小切開（Endoscopic Minilaparotomy） 根治的腎摘除術}

\footnotetext{
東京医科㐘科大学大学院 尿路生殖機能学（泌尿器科）11

影山 幸雄" 岡田 洋平" 新井 学" 兵地 信彦" 鈴木 理仁" 増田 均”林哲夫"川上 理”奥野哲男" 石坂 和博" 木原和徳"

【目的】限局性腎細胞癌に対し3〜5横指の単一小切開創から経腰 的根治的腎摘除を施行し，その有用性を検剸した【術式】1） 腎摘位にて第 12 肋骨先端部に3〜5横指（5１0cm）の小切開をお き、適宜，同肋骨先端部を除去した。2） $30^{\circ}$ の胸腔鏡を創から 㨉入し以後の操作を行った。3）Gerota筋膜の後葉を剥離し留茎 部を展開、腎動脈、次いで韰静脈を結紮切断した。4) Gerota筋 膜前葉と腹膜との間を剥離したのち、尿管を結禁切断。5)Gerota 筋膜の上方を剥離し副腎とともに腎を摘出した。深部の結紮は結 紮器を用いたがそれ以外は通常の手術器具を用いた。【結果】1) 出血量 $62 \sim 1,916 \mathrm{ml}$ (下大静脈を損傷した1例を除くと62 600 $\mathrm{ml}$ )、 手術時間132〜278分。2）術翌日から食事・歩行が可能であっだ。 3) 使い捨て器具、炭酸ガスは使用せず、合併症はみられなかっ た。4）手術参加者全員が深部操作を観察し得た。【考察】3〜5 横指の単一小切開創から行う根治的腎摘除術は有用な手術法と考 えられる。
}

腎癌 ミニラパロトミー 腹腔鏡

\section{$\mathrm{V}-16$}

\author{
日鋼記念病院 泌尿器科" 日鋼記念病院 東室珮サテライトクリニック \\ 日鋼記念病院 外科・腎センター ${ }^{31}$ 日鋼記念病院 検体検查科 \\ 榎並 宣裕 ${ }^{1}$ 森田 研”伊丹儀友 ${ }^{21}$ 大平 整爾 ${ }^{3}$ \\ 高橋 達郎 ${ }^{4}$
}

症例は52歳男性。慢性系球体腎炎にて 3 年 8 力月前より血液透析 を施行中 (無尿)。定期検査のC Tにて両側腎下極に径 $1-2 \mathrm{~cm}$ の腎腫瘍を認めた。人工血管アクセスの 閉塞防止にワーファリ ンを使用しており、術前にへパリン間歇投与に変更した。1Lの 自己血貯血を準備し、両側腎摘出を行った。仰卧位にて湾上部に $7.5 \mathrm{~cm}$ の腹部正中切開を加えてハンドアシスト用デバイスを装着 し、患側と同側の術者手を挿入し、腹腔鏡ポートを挿入した。腹 䏕内に挿入したタオルで腸の圧排・渗出液吸収を行った。両側と 屯、腎上極以外は周井脂肪組織を十分付けて腎を剥離し、腎血管 ・尿管はEndoClip及びEndoGIAで結紮切断した。摘出重量は左 $336 \mathrm{~g}$ 、右 $367 \mathrm{~g}$ であった。手術時間 5 時間46分、出血は微量、術中 自己血を $200 \mathrm{ml}$ 投与した。病理所見はRCC, G1>2, Tlaであっ た。術後透析管理に支障無く、離床や経口摂取が早期に行え、術 後合併症を認めなかった。ハンドアシスト腹胿鏡手術は、腹腔鏡 単独手術と比較し、同等の不感蒸泄・熱放散・術後回復・疼痛で 開腹手術同等の摘出標本が得られ、全て刺入法のポート挿入・触 覚による組織把握・タオルや手術機械の持ち込みがで可能である。 開腹手術と比較して、多人数で共有できる搪大された術野が得ら れ、摘出場所に因らない筋無切切開を選択でき、今後適応症例の 增加が見込まれる。

両側腎癌 ハンドアシスト手術透析 